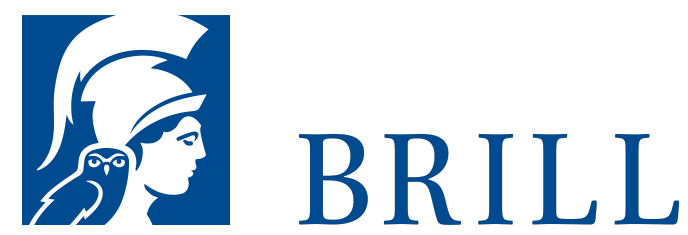

\title{
Gut in allen möglichen Welten
}

\author{
Der ethische Horizont \\ Author: Peter Strasser
}

Die kritische Diagnose des Buches lautet: Ein Großteil der nachmetaphysischen Ethik, die heute den Ton angibt, ist innerlich defekt. Sie leidet an einem Zuviel an Säkularisierung. Jede Moral, die den Anspruch auf Universalität zu Recht erhebt, hat einen metaphysischen Horizont: das absolut Gute. Das absolut Gute ist dasjenige, was wir um seiner selbst willen anstreben. Es ist gut in allen möglichen Welten, unabhängig davon, was hier und jetzt für gut befunden wird. Gegen die zunehmende Immanenzverdichtung wird argumentiert, dass die Ethik wesenhaft auf zwei Grundpfeilern ruht. Erstens: Die transzendente Freiheit des Ichs ist eine Voraussetzung der Moral. Daher scheitern die Naturalisten, wenn sie den biologischen Menschen zugleich als ethisches Subjekt denken. Zweitens: Der Mensch ist nicht begreifbar als der Schöpfer seiner eigenen Werte. Daher muss der ethische Subjektivismus falsch sein. Gezeigt wird, wie unter dem Vorzeichen der Moderne, die auf kulturellem Gebiet relativistisch verfährt, dennoch ein visionärer Objektivismus in der Moral überlebt. Werte sind Wertpotentiale, deren Wahrheitsgehalt die Vielfalt benötigt, um sich zu offenbaren. Inhalt: Einleitung Teil A: Die Richtung des Guten I. Das Gute und das Gesollte II. Von Werten zu Normen III. Die ethische Blindheit des Naturalismus IV. Die Transzendenz des Guten V. Die Nichtkontingenz der Werte VI.... See More

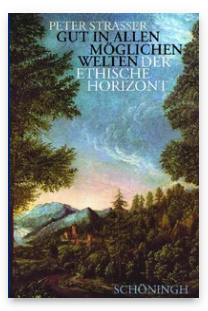

Pages: 286

Seiten

Language:

German

Subjects:

General,

Philosophy

Publisher: Brill |

Schöningh

E-Book (PDF)

Released online:

$15 \mathrm{Jul} 2019$

ISBN: 978-3-

657-7176o-6

List price

USD $\$ 63.00$

Paperback

Publication date:

21 May 2008

ISBN: $978-3-$

5०6-7176o-3

List price

USD $\$ 63.00$ 
For more information see brill.com

Order information: Order online at brill.com +44330 333 0049 | customerservices@brill.com Submission information: brill.com/authors

Titles published by Brill | Fink, Brill | mentis or Brill | Schöningh: +49(o)715413279216| brill@brocom.de 